\title{
CORRIGENDUM
}

\section{In the grip of worry: cerebral blood flow changes during worry induction and reappraisal in late-life generalized anxiety disorder}

HT Karim, DL Tudorascu, MA Butters, S Walker, HJ Aizenstein and C Andreescu

Translational Psychiatry (2017) 7, e1244; doi:10.1038/tp.2017.215; published online 26 September 2017

Correction to: Translational Psychiatry (2017) 7, e1204; doi:10.1038/tp.2017.180; published online 15 August 2017

On the penultimate line of Table 1, the last paragraph of Results (Effect of worry severity) and the first paragraph of Discussion, the wrong lobe was stated. In the text, 'right superior parietal lobe' should replace 'left superior parietal lobe'; for Table 1 it should read 'Right SPL/PoCG' instead of 'Left SPL/PoCG'.
This work is licensed under a Creative Commons AttributionNonCommercial-NoDerivs 4.0 International License. The images or other third party material in this article are included in the article's Creative Commons license, unless indicated otherwise in the credit line; if the material is not included under the Creative Commons license, users will need to obtain permission from the license holder to reproduce the material. To view a copy of this license, visit http:// creativecommons.org/licenses/by-nc-nd/4.0/

(c) The Author(s) 2017 